\title{
WAQF ASSET MANAGEMENT FOR WATER FACILITIES
}

\author{
Asma' Munifatussa'idah' ${ }^{1}$ \\ ${ }^{1}$ Islamic Economics, Faculty of Economics and Business, Airlangga University
}

\begin{abstract}
The increasing number of waqf practices in providing solutions for the welfare of Muslims has demonstrated the role of waqf in the social and economic life of society. The purpose of this study is to investigate the implementation of waqf asset management for in-water facility projects as well as waqf risk management in Badan Wakaf Al-Qur'an (BWA) Indonesia. On a water facilities waqf project, this study employs a qualitative study with an explanatory approach. The study relies on primary data gathered from interviews with the program manager. The findings show that by involving the community as the manager of the waqf assets, waqf asset management in the water facilities project in Muara Gembong, Bekasi, can be productively empowered. Adjustment, assessment, planning, fundraising, realization, monitoring, and evaluation are all part of Waqf asset management for water facilities. The benefits of water facilities are intended for consumption and to improve the economy of the beneficiary community.
\end{abstract}

Keywords: waqf asset management; water facilities; Badan Wakaf Al-Qur'an.

*Corresponding author: asma.munifatussaidah-2019@feb.unair.ac.id

Received: July 07, 2019; Accepted: October 01, 2021; Published: December 16, 2021

\begin{abstract}
Abstrak: Peran wakaf dalam kehidupan sosial dan ekonomi masyarakat dibuktikan dengan semakin banyaknya praktik wakaf dalam memberikan solusi bagi kesejahteraan umat Islam. Penelitian ini bertujuan mengkaji implementasi pengelolaan aset wakaf pada proyek fasilitas air bersih dan pengelolaan risiko wakaf di Badan Wakaf Al-Qur'an (BWA) Indonesia. Penelitian ini menggunakan jenis penelitian kualitatif dengan pendekatan eksplanatori, pada proyek wakaf sarana air bersih. Sumber data dalam penelitian ini adalah data primer, melalui wawancara dengan manajer program. Hasil penelitian menunjukkan pengelolaan aset wakaf pada proyek sarana air minum di Muara Gembong, Bekasi, dapat diberdayakan secara produktif dengan melibatkan peran masyarakat sebagai pengelola aset wakaf. Pengelolaan aset wakaf sarana air yang terdiri dari penyesuaian, penilaian, perencanaan, penggalangan dana, realisasi, pemantauan,
\end{abstract}


dan evaluasi. Manfaat dari aset wakaf fasilitas air akan ditujukan untuk konsumsi dan meningkatkan perekonomian masyarakat penerima.

Kata kunci: Manajemen Aset Wakaf; Sarana Air; Badan Wakaf Al-Qur'an.

\section{INTRODUCTION}

In terms of commerce, Waqf is the most noble Jariyah. The role of waqf in society's social and economic life has been established. It is carried out by a growing number of waqf practices that have been successful in presenting solutions for the welfare of Muslims. The capacity for waqf is expanding both in Indonesia and globally, in tandem with the growing focus of the Muslim network that uses waqf as a form of worship. (Bank Indonesia, 2016). The concept of waqf, which must preserve its asset cost, is a completely unique feature in collecting, managing, and utilizing its benefits. However, several issues remain in the practice of waqf management due to traditional tendencies, minimal improvement in innovation, and a lack of professionalism in governance. Furthermore, the use of waqf is restricted to spiritual and social activities.

The general public of waqf land in Indonesia is used for 44.22 percent of mosques, 28.27 percent of prayer rooms, and 10.68 percent of educational institutions out of the 53.2 thousand hectares with 398.5 thousand locations. (SIWAK, 2021). It implies that the use of waqf assets is not productively controlled and is limited to the purchase of land and homes for social purposes. Meanwhile, looking at the capability of waqf, both its assets and valuable values can be used for a larger cause, affecting the economic welfare of human beings, and being a solution to poverty issues in various regions of Indonesia.

Waqf management that is productive means that it is far used in efficient activities with economic value, and the benefits can continue to flow without lowering the principal value of the waqf assets. The effects of asset productivity can be distributed in accordance with the cause of waqf, or the Manager can use the value of the benefits (Nazhir) (Choiriyah, 2017). As a result, waqf will continue to grow and gain value and advantages. In other words, waqf assets include a component of future investment by developing assets productively for future generations. The issue with managing efficient waqf is figuring out how to control it so that the outcomes of the waqf assets can be evolved to improve the society's economic system. (Rozalinda, 2016). As a result, there is no reason for waqf not to provide all assets and capitalize on the value of advantages. (Syakir, 2016).

Alternatively, the productive waqf, which has been implemented by several waqf establishments (Nazhir), is still constrained within the distribution of benefits from productive waqf assets, which can be used primarily by beneficiaries in terms of consumptive, rather than assets for a business or education. (Seprillina et al., 2019). Similarly, productive waqf activities can pose some risks in modern waqf management practices that emphasize efficiency in dealing with waqf property productively. (Khalid et al., 2019). These include the possibility of impairment, a 
lack of waqf assets, and operational risks. As a result, it necessitates a high-intensity analysis that includes the identification and planning process to mitigate the risk of both low-risk and high-risk productive activities. (Bank Indonesia, 2016).

As a result, professional nazhir and managerial competence are required to complete the purpose of waqf in achieving social justice and welfare. (Habibaty, 2020). In this situation, the function of Nazhir is as the recipient, manager, and empowerment of waqf funds in giving desire to all parties in efforts to empower efficient economies, in addition to the pursuits of worship and other public social fascilities. (Rusydiana et al., 2020). As a consequence, the Nazhir strategy must be productively developed in order to expand the lifestyles of waqf as a distinct socialIslamic instrument.

Badan Wakaf Al-Qur'an (BWA) is a waqf institution (Nazhir) that professionally manages waqf assets and has innovative programs like water activities for people, power generation facilities, productive waqf, dakwah vessels, and other innovative programs. (Badan Wakaf Al-Quran, 2021a). BWA was chosen as a waqf institution capable of providing an independent and independent waqf asset management scheme in this study. BWA has 95,196 individual waqf donors as of April 9, 2021. (Wakif). The Program of "Water Action for People" through water facilities is one of BWA's masterpiece programs. The program was managed in a productive manner for the people's economic well-being. Projects from the "Water Action for People" Program have a relatively large waqf asset value and high benefits. (Badan Wakaf Al-Quran, 2021c).

Several previous studies on the productive waqf have been conducted (Rozalinda, 2016; Saadah, 2016; Seprillina et al., 2019; Suryanto et al., 2020; Wahyuningsih \& Widiyastuti, 2018; Zainal \& Lupitasari, 2017). Furthermore, previous research on waqf of water facilities with a Maqashid Sharia approach does not explain risk management of waqf assets. (Darnis, 2019). Meanwhile, this study will look at the technical aspects of managing productive waqf asset management in waqf institutions (Nazhir), such as the risk management of waqf assets. The goal of this research, as stated above, is to discover how to implement productive waqf asset management for the Badan Wakaf Al-Qur'an (BWA) in a water facility waqf project, including management processes, fundraising, development, utilization, and evaluation. This study focuses on the water facility's "Water Action for People" program. This research is critical because it will provide a plan for implementing productive waqf asset management in a water facilities project in order to improve the economy of society. 


\section{RESEARCH METHOD}

Based on the research objectives, namely productive waqf asset management in Badan Wakaf Al-Qur'an (BWA), Jakarta, this study employs a qualitative research approach with an explanatory approach. The subject of this research is found in the Badan Wakaf Al-Qur'an (BWA). This study's main topic of discussion is the Waqf Project for Water Facilities from "Water Action for People."

This study's primary data source is online interviews with informants about waqf asset management in the "Water Action for People" Program. The informants for this study were the Division 1 Program Manager and the Division 2 Program Manager at the Badan Wakaf Al-Qur'an (BWA), Jakarta, in order to obtain an explanation of waqf asset management. Interviews were held on April 1st and 7th, 2021. The secondary data was obtained through literature studies, which included reviewing various journals, books, reports, regulations, and policies pertaining to waqf asset management. Secondary data is used to supplement the primary data obtained through online interviews with informants.

Online interviews and documentation are used to collect research data. The data research is then analyzed by reducing, presenting, and drawing conclusions from the information obtained, resulting in a solution to research problems. (Sugiyono, 2017). Furthermore, after analyzing the data, the data is interpreted using the pattern matchmaking data technique, with the goal of comparing the theory with the information obtained from the data (Yin, 2011).

\section{RESULTS AND DISCUSSION}

\section{Profile of Research Object}

Badan Wakaf Al-Qur'an (BWA) is an Islamic philanthropic institution that collects waqf funds from Muslims (Wakif) and distributes them through waqf programs. St. Tebet Timur Dalam I No. 1, Tebet District, South Jakarta, and DKI-Jakarta are the addresses of BWA's headquarters. BWA was founded in 2005, as evidenced by the Notary Deed of H. Rizul Sudarmadi Number 119, dated April 28th, 2005. MUI welcomed and supported BWA on June 1st, 2006, in accordance with MUI Recommendation Letter Number U-217/MUI/VI/2006. (Badan Wakaf Al-Quran, 2021a).

\section{Profile of Water Action for People Program BWA}

"Water Action for People" is a waqf program that builds clean water facilities in remote areas of Indonesia that are experiencing a clean water crisis and have been affected by natural disasters. The goal of this program is to build water facilities and foster communities in the surrounding area that are known as waqf recipients by providing sanitation, education, and Islamic education. The "Water Action for People" program began in 2006, with its first project waqf for clean water facilities. On April 31st, 2020, a clean waqf was successfully constructed. Water facilities are dispersed throughout the city. This program tells the story of the waqf "Raumah Well" in Medina, which was owned by Khalifah Utsman bin Affan r.a. and helped 
the people of Medina with their lack of clean water. Until now, waqf "Raumah Well" has provided blessings that continue to flow and are long-lasting foranyone. (Badan Wakaf Al-Quran, 2021b).

BWA's "Water Action for People" program is led by Program Manager 1 and the executive team. In terms of the productiveness blessings of waqf assets, this program collaborates with field partners. Waqf for Water Facilities, located in Pantai Bahagia Village, Muara Gembong, Bekasi, and West Java, is one of the projects that have been realized and managed successfully through this program. Muara Gemong Water Facility was officially announced as part of the Waqf program on Thursday, February 4th, 2021, with a waqf asset value of 1.79 billion rupiah. Waqf of Muara Gemong Water Facility is one of the successful BWA waqf projects that can support the availability of "clean water" as well as the economic necessity of the beneficiary community. The Waqf Project's Muara Gembong Water Facility is also managed independently by the community as BWA's field partners. (Nazhir) (Badan Wakaf Al-Quran, 2021c).

\section{BWA Waqf Asset Management}

The waqf asset management application has six stages, with the waqf object being clean water facilities. The stages are based on the findings of interviews with informants from BWA's Program Managers 1 and 2 in Jakarta. Figure 1 shows how these six stages are applied not only to the Water Action for People Program, but also as a whole. The reason for this is as follows:

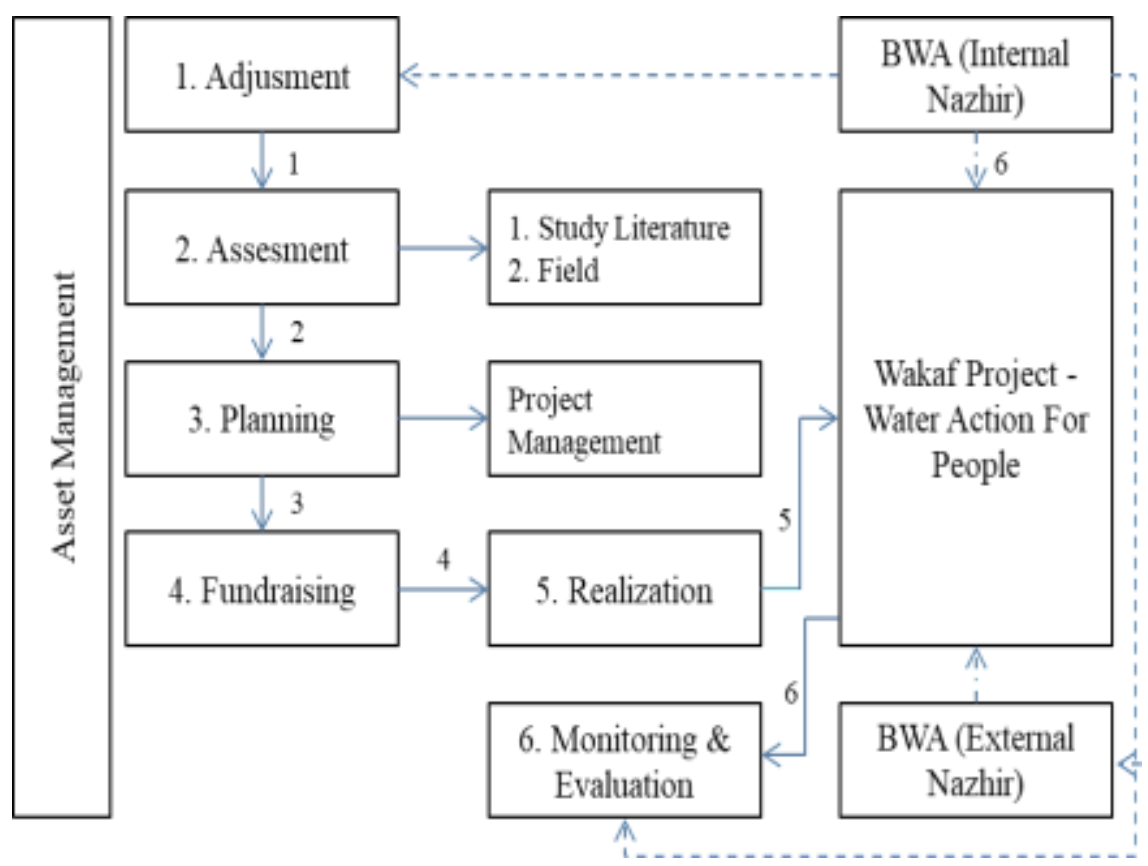

Figure 1. BWA's Waqf Asset Management

Source: Compilation from the Interview (Authors Illustration, 2021) 
Stages of agreement (Ijab Qabul) have determined a new project from the Water Action for People Program between the program team, which consists of the Program Manager and project implementing members, and BWA's directors. This agreement was reached in order to determine what issues are currently causing problems in the community prior to conducting a survey and assessment.

The program team's assessment stage employed a self-assessment approach in two ways: an assessment based on a literature review and a survey of field conditions. To begin, the literature study assessment seeks information on project ideas and problems from the internet, books, or magazines. During this assessment phase, the program team received field information about the drought in Muara Gembong.

Furthermore, the location (field) assessment is armed with information from parties who can interact with the community, where the program team conducts a direct survey to Pantai Bahagia Village, Muara Gembong, Bekasi, by boat because the location has limited transportation access and is located on the border between Bekasi and the Java Sea and the Citarum River. To obtain accurate information and data, the site assessment process is completed on a continuous basis. After arriving at the site, the program team identified three aspects: "social, technical, and Islamic." Social aspects, such as identifying social problems in Muara Gembong, such as how culture, religion, environment, and someone as a role model, can be used to identify the responsible person of water sources in Pantai Bahagia Village. In order to obtain social information, the program team approached the society in order to establish social relationships. Following a site survey, it was discovered that the location lacked any fresh or clean "water source," so the community was forced to wait for water vendors from the next village to pass by.

Furthermore, following problems with "clean water" for consumption, the program team identified a technical aspect, that is, finding the right technology that could be used in the long run, to solve problems in Pantai Bahagia, Muara Gembong Village, Bekasi, which has 2,127 families or 7,726 people. The assessment concludes with an Islamic or religious aspect, by proposing a waqf scheme for water facilities as waqf assets in Pantai Bahagia Muara Gembong and seeking parties as a Nazhir. Nazhir was chosen from the Muara Gembong society to manage and report on the status of the clean water waqf project's utilization.

Planning and management, the Nazhir must be in charge of all aspects of waqf planning, organizing, directing, and supervising. (Saadah, 2016). The social, technical, and Islamic assessments provided information to the program team. Furthermore, project planning is done using a logical framework, and the program team creates a problem tree that aims to map problems from priority to zero priority; this is done to avoid future risks, which is known as early-risk mitigation. When deciding on a technology to use, the program team must consider the various consequences. The proposed project plan for Pantai Bahagia, Muara Gembong, based on field studies, includes groundwater drilling in Gobah Village to obtain brackish water "Raw Water." Construction of desalination equipment houses; 
acquisition of brackish water desalination equipment using reverse osmosis (RO) technology.

The program team then drafted a concept or design proposal, which was presented to the Board of Directors for approval after mapping the problems and determining community needs. After the proposal is approved, the project in Pantai Bahagia Muara Gembong Village will proceed to the stage of public publication (Wakif), both for individuals and businesses, in BWA known as the "naik web" process. Furthermore, the realization planning process determines who will be responsible, including the waqf institution, field partners, equipment contractor vendors, RAB, as well as the costs and time length required to work on this project. The total cost of the water facility project is 1.7 billion rupiah, with water facilities being the waqf object. Then it will take three years to work on it until it becomes a reality. Then it will take three years of hard work to see it through.

Fundraising requires careful planning on the part of the Nazhir in order to set a goal for the waqf program (Saadah, 2016). The value of the waqf assets has been determined, and the fundraising process has begun. The Fundraising Team got to work right away to raise project funds so that the project could be completed on time. BWA collects waqf funds in a variety of ways, including crowdfunding, fundraising from branch offices, the Digital Corporate Fund (DCF) to raise Corporate Social Responsibility (CSR), telefundraising, and fundraising through online and offline systems.

The program team began working on the project in stages with existing funds during the fundraising process. On February 14th, 2021, the program team, in collaboration with the Geophysic Team from Bandung, conducted the Geoelectric Test in Pantai Bahagia, Muara Gembong Bekasi. The Muara Gembong society, team BWA, and field partners participated in the test to detect the aquifer layer for water drilling. Two measurement points in Gobah Village were sampled for a geoelectric test. After locating the brackish water aquifers point, drill to a depth of 85 meters to obtain raw water and then begin the desalination process. Phase II will be realized in November 2019 by constructing a desalination house as a location or tools for filtering and converting brackish water into fresh water suitable for direct consumption by Muara Gembong residents. Desalination plants will be operational from December 2019 to January 2020 was completed, and residents were allowed to consume water for free after undergoing a water quality trial with a lab test in accordance with the provisions of the feasibility of drinking water.

As it should be from Saadah (2016) The Nazhir develops procedures for developing waqf assets for the community's long-term benefit and welfare. However, mastery of the risks that can occur is also required at this stage, so Nazhir's capabilities and competencies are required in suppressing or mitigating the potential risks of productive waqf. 
Furthermore, after all construction processes are completed, BWA will inaugurate the waqf for water facilities at Pantai Bahagia Muara Gembong Bekasi in February 2021. The "B Water" depot can be used as a productive waqf. The handover was carried out by BWA in the presence of village community leaders, as well as the inauguration of the parties responsible for water productivity in the field. The waqf assets for the Muara Gembong water facility project include a boat, depot, a set of desalination machines and equipment, and a submersible pump with a depth of 90 meters. The Muara Gembong water facility waqf project, in collaboration with field partners, aims to preserve waqf assets while utilizing economically valuable water.

Then the utilization of benefits from the assets of clean water facilities, it is taked by means of water from process desalination result, in the form of consumable mineral water that is traded to drive Muara Gembong's economy. The sales profit proceeds water is entirely for the maintenance of waqf assets and salaries or some residents who are entrusted with maintaining and manage waqf assets of water facilities. With realization of clean water waqf facilities, it is expected to be able to overcome the difficulties of clean water in Muara Gembong, as well as be continuously empowered to increase the economy of the village society.

Evaluation and reporting, the Nazhir report the outcomes of waqf activity realization, such as transparent financial reports with waqf, individuals and communities, and companies for fund raising. (Saadah, 2016). Monitoring and evaluation stages in BWA' waqf program are after the project endowment for water facilities in Muara Gembong was inaugurated. After it is launched, it is monitored on a monthly, semester, and annual basis to identify any obstacles or risks. At this point, the results obtained during the course of the project have also been completed, and the notes have been reported by the BWA's external Nazhir to the BWA program team as the internal Nazhir. Monitoring is carried out both offline and online. Six months of online monitoring are conducted, while the offline stage is conducted directly in the field to review problems that arise at the location, particularly the function of technology.

Then comes the monitoring evaluation stage, which is the program team's action or response to problems that arise in order to find solutions. Return to the planning stage for the problem that occurred once the solution has been obtained. During the evaluation planning stage, the program team decides what should be done, what solutions should be provided, and what documents should be written to address the problem. The program team invites and consults field partners to help solve existing problems. The monitoring and evaluation stage is critical and difficult because BWA involves the community in managing the outcome of waqf benefits, as well as maintaining the core value of waqf assets with the benefits that continue to flow.

\section{BWA Waqf Risk Management}

The program team explained the risk management of waqf assets that are vulnerable to risk based on the results of the interviews by identifying risks that may arise since the determination and planning of the water facilities waqf project. The program team then analyzed and mapped the risks from high to low, identifying which 
projects were high and low risk. This was done because the value of waqf assets was classified as high, with a high value of benefits as well. Following that, if a potential risk emerges during the rationalization process, the program team begins looking for ways to control the existing risks, such as when the land waqf for the sanitation location was driven out, BWA will immediately take action by redirecting project funds to other projects.

Social risk can also occur; however, this risk becomes an impediment at the beginning of the process assessment, increasing the costs incurred. When local communities are unable to receive assistance from waqf institutions, project implementation suffers. One of the impediments is that when some residents control water sources, it will be difficult to negotiate with them, so the program team must build extra trust with local residents. Other risks, as natural disasters occur, the BWA program team will evaluate whether the risk is transferred to another location, returned to waqf, repaired, or replaced with new technology.

This risk is known as operational risk, and it is related to waqf's institutional functions such as management, practices, and procedures, as well as policy formulation. Losses in internal processes, human resources, and inadequate systems for assessing external conditions all contribute to this risk. The occurrence of operational risk will result in an increase in operating costs, as well as a decrease in Nazhir's income (Khalid et al., 2019).

Furthermore, the two informants explained that the reputation is a risk that is likely to occur among the three operational risks of activities, the institution's reputation in the public perception, and the risk of benefits sharing on productive waqfassets, as the results of interviews. Based on Khalid et al. (2019) Risk to one's reputation, as it relates to public trust in services. Because Nazhir's performance is considered less-mandated to manage waqf assets, this risk is caused by a decrease or even loss of public trust in Nazhir. If this occurs, Nazhir will lose a partner. As a result, the greater public trust in Nazhir's performance, the lower the possibility of reputation risk.

This is due to the importance of explaining social risks associated with maintaining social relationships and trust with the community for services or programs and projects proposed by BWA to beneficiaries. Not everyone readily accepts the waqf scheme, which contains many Islamic elements. Then there is the reputation of BWA and field partners who move and collaborate with BWA to maintain and manage waqf assets. Following the mitigation and control process, as in the waqf asset management stage, this stage becomes a process that must be followed on a regular basis to ensure that there is no risk of the same. This stage includes BWA's (Ikhtiar) efforts in preserving waqf assets and ensuring sustainable waqf.

According to the Risk of Benefit Distribution, Nazhir planning in empowering the benefits of waqf assets. Poor planning will result in the benefits of productive waqf assets being distributed. So the better the direction of distributing the value of 
benefits to the beneficiaries, the better the Nazhir planning (Mauquf alaih) (Bank Indonesia, 2016; Khalid et al., 2019).

\section{CONCLUSION}

According to the findings of the interviews, the Al-Qur'an Waqf Agency (BWA) is able to use "payuh water" as a source of fresh water suitable for consumption by empowering water facilities as waqf assets through the "Water Action for the People" program. With a trusted and professional management process in the form of groundwater drilling, construction of desalination houses, and procurement of desalination equipment, BWA is able to provide solutions to community problems in Pantai Bahagia Village, Muara Gembong, Bekasi. The process of managing waqf assets then includes planning, fundraising, realization, and monitoring and evaluation. BWA includes waqf risk management in the implementation of waqf asset management, which consists of risk identification, analysis, mapping, control and mitigation, and risk evaluation monitoring. The term "reputation risk" is used by BWA to describe an area that is vulnerable to risk. Although operational risks and benefit distribution must also be considered by waqf practitioners. The stages and processes of waqf management performed by BWA demonstrate that Nazhir not only manages land and building waqf, but water facilities are also an object of waqf. Waqf benefits are obtained in mineral water suitable for consumption and according to production price in waqf asset management.

As a result, the findings of this study analysis are hoped to be useful for other Nazhir as an example of professional and systematic waqf management of water facilities. The study's limitation is that it only obtained information from the program manager. As a result, recommendations for future research can use and incorporate additional methods to obtain more detailed information.

\section{REFERENCES}

Badan Wakaf Al-Quran. (2021a). Program Profil Badan Wakaf Al-Qur'an. Badan Wakaf Al-Qur'an Indonesia. https://www.wakafquran.org/

Badan Wakaf Al-Quran. (2021b). Program Wakaf Produktif Badan Wakaf AlQur'an. Badan Wakaf Al-Qur'an Indonesia. https://www.wakafquran.org/

Badan Wakaf Al-Quran. (2021c). Program Water Action for People Badan Wakaf Al-Qur'an. Badan Wakaf Al-Qur'an Indonesia. https://www.wakafquran.org/ Badan Wakaf Indonesia. (2021). Wakaf Produktif. Badan Wakaf Indonesia.

Bank Indonesia. (2016). Wakaf: Pengaturan dan Tata Kelola yang Efektif. Seri Ekonomi dan Keuangan Syariah. In Isbn (Pertama). Departemen Ekonomi dan Keuangan Syariah - Bank Indonesia.

Choiriyah. (2017). Wakaf Produktif dan Tata Cara Pengelolaannya. Islamic Banking: Jurnal Pemikiran Dan Pengembangan Perbankan Syariah, 2(2), 25- 
34. http://www.ejournal.stebisigm.ac.id/index.php/isbank/article/view/29 Darnis, D. (2019). The Utilization of Waqf Funds on the Water Action for People Program in the Al Quran Waqf Agency Based on the Maqashid of Sharia Perspective. Millah, 19(1), 137-166. https://doi.org/10.20885/millah.vol19.iss1.art7

Departemen Agama. (2008). Wakaf. Kementrian Agama RI.

Dikuraisyin, B. (2020). Manajemen Aset Wakaf Berbasis Kearifan Lokal Dengan Pendekatan Sosio-Ekonomi di Lembaga Wakaf Sabilillah Malang. Ziswaf: Jurnal Zakat Dan Wakaf, 7(2), 100. https://doi.org/10.21043/ziswaf.v7i2.7903 Djunaidi, A. (2005). Paradigma Baru Wakaf di Indonesia. Direktorat Pengembangan Zakat dan Wakaf Departemen Agama RI.

Effendi, M. R. (2021). Development of Cash Waqf Benefits Synergy Foundation in the Economic Empowerment of the Ummat. Amwaluna: Jurnal Ekonomi Dan Keuangan Syariah, 5(1), 29-39.

Habibaty, D. M. (2020). Kompetensi Nazhir Pada Wakaf Produktif Ditinjau Dari Undang-Undang No 41 Tahun 2004 Tentang Wakaf. Al-Awqaf: Jurnal Wakaf Dan Ekonomi Islam, 10(2), 154-161.

Indonesia, B. W. (2016). Pedoman Akuntansi Wakaf. In Departemen Agama. Khalid, M. M., Yaakob, M. A. Z., Bhari, A., \& Mohamed Yusof, M. F. (2019). Risk Management in Waqf Institutions: A Preliminary Study. Journal of Fatwa Management and Research, 16(2), 207-219. https://doi.org/10.33102/jfatwa.vol16no2.16

Rozalinda. (2012). Manajemen Risiko Investasi Wakaf Uang. ISLAMICA: Jurnal Studi Keislaman, 6(2), 300-315. https://doi.org/10.15642/islamica.2012.6.2.300-315

Rozalinda. (2016). Manajemen wakaf produktif di sumatera barat. Al-Awqaf: Jurnal Wakaf Dan Ekonomi Islam, 9(2), 137-155.

Rustam, B. R. (2018). Manajemen Risiko Perbankan Syariah di Era Digital: Konsep dan Penerapan di Indonesia. Salemba Empat.

Rusydiana, A. S., Hidayat, Y., Widiastuti, T., \& Rahayu, S. S. (2020). Developing Islamic Economy Through Cash Waqf Instrument: Case Study in Indonesia. Al-Uqud: Journal of Islamic ..., 5(28), 43-59. https://doi.org/10.26740/aluqud.v5n1.p43-59

Saadah, N. (2016). Manajemen Wakaf Produktif : Studi Analisis Pada Baitul Mal Di Kabupaten Kudus. EQUILIBRIUM: Jurnal Ekonomi Syariah, 4(2), 334- 352. Seprillina, L., Qurrata, V. A., Narmaditya, B. S., \& Hussain, N. E. B. (2019). The Effectiveness Productive Waqf as a Social Welfare Development Through Community Empowering: A Case in Islamic Hospital Foundation Malang. Review of Integrative Business and Economics Research, 9(3), 67-74. 
SIWAK, K. (2021). Data Wakaf: Luas Tanah, Lokasi, dan Penggunaan Wakaf. http://siwak.kemenag.go.id/

Sugiyono. (2017). Metode Penelitian Bisnis Pendekatan Kuantitatif, Kualitatif, Kombinasi, dan $R \& D$ (3rd ed.). Alfabeta.

Suryanto, A., Zulfikri Rahmat, B., \& Marlina, L. (2020). Islamic Philanthropy: Waqf Empowerment of Madina Minimarket In Tasikmalaya - Indonesia. Ikonomika: Jurnal Ekonomi Dan Bisnis, 5(1), 1-16. https://doi.org/10.24042/febi.v5i2.5315

Syakir, A. (2016). WAKAF PRODUKTIF. July, 0-16.

Tandelilin, E. (2010). Analisis Investasi dan Manajemen Portofolio. Badan Penerbit Fakultas Ekonomi.

Wahyuningsih, \& Widiyastuti, T. (2018). Efisiensi Wakaf Produktif Pada Yayasan Badan Wakaf Sultan Agung Semarang. Al-Awqaf: Jurnal Wakaf Dan Ekonomi Islam, 11(2), 141-152.

Widiastuti, T., Wisudanto, Rusgianto, S., Sukmana, R., \& Alhidayati Asymal. (2019). Wakaf Amerta (Pertama). Airlangga University Press.

Yin, R. K. (2011). Studi Kasus Desain \& Metode. PT RajaGrafindo Persada. Zainal, V. R., \& Lupitasari, C. I. (2017). Model Pengelolaan Wakaf Produktif di Pondok Modern Darussalam Gontor dan Perannya terhadap Pengembangan Universitas Darussalam Gontor. Al-Awqaf: Jurnal Wakaf Dan Ekonomi Islam, $10(1)$. 